Article

\title{
Rational Design and Synthesis of New, High Efficiency, Multipotent Schiff Base-1,2,4-triazole Antioxidants Bearing Butylated Hydroxytoluene Moieties
}

\author{
Wageeh A Yehye ${ }^{1, *}$, Noorsaadah Abdul Rahman ${ }^{2,3}$, Omar Saad ${ }^{4}$, Azhar Ariffin ${ }^{2}$, \\ Sharifah Bee Abd Hamid ${ }^{1}$, Abeer A. Alhadi ${ }^{2,3}$, Farkaad A. Kadir ${ }^{5}$, Marzieh Yaeghoobi ${ }^{2,3}$ \\ and Abdulsalam A. Matlob ${ }^{6}$ \\ 1 Nanotechnology \& Catalysis Research Centre (NANOCAT), University of Malaya, Block 3A, \\ Institute of Postgraduate Studies Building, Kuala Lumpur 50603, Malaysia; sharifahbee@um.edu.my \\ 2 Department of Chemistry, Faculty of Science, University of Malaya, Kuala Lumpur 50603, Malaysia; \\ noorsaadah@um.edu.my (N.A.R.); azhar70@um.edu.my (A.A.); aaalhamadani@yahoo.com (A.A.A.); \\ m.yaeghoobi@gmail.com (M.Y.) \\ 3 Drug Design and Development Research Group, Department of Chemistry, Faculty of Science, \\ University of Malaya, Kuala Lumpur 50603, Malaysia \\ 4 Department of Pharmacy, Faculty of Medicine, University of Malaya, Kuala Lumpur 50603, Malaysia; \\ omar79@siswa.um.edu.my \\ 5 Division of Human Biology, School of Medicine, International Medical University, \\ Kuala Lumpur 57000, Malaysia; FarqadAbdulhadi@imu.edu.my \\ 6 Department of Environmental Technology, College of Environment, Mosul University, Mosul 41001, Iraq; \\ matlob58@yahoo.com \\ * Correspondence: wdabdoub@um.edu.my; Tel.: +60-3-7967-6954; Fax: +60-3-7967-6556 \\ Academic Editor: Fawaz Aldabbagh \\ Received: 5 June 2016; Accepted: 24 June 2016; Published: 28 June 2016
}

\begin{abstract}
A new series of multipotent antioxidants (MPAOs), namely Schiff base-1,2,4-triazoles attached to the oxygen-derived free radical scavenging moiety butylated hydroxytoluene (BHT) were designed and subsequently synthesized. The structure-activity relationship (SAR) of the designed antioxidants was established alongside the prediction of activity spectra for substances (PASS). The antioxidant activities of the synthesized compounds 4-10 were tested by the DPPH bioassay. The synthesized compounds 4-10 inhibited stable DPPH free radicals at a level that is $10^{-4} \mathrm{M}$ more than the well-known standard antioxidant BHT. Compounds 8-10 with para-substituents were less active than compounds $\mathbf{4}$ and $\mathbf{5}$ with trimethoxy substituents compared to those with a second BHT moiety (compounds 6 and 7). With an $\mathrm{IC}_{50}$ of $46.13 \pm 0.31 \mu \mathrm{M}$, compound 6 exhibited the most promising in vitro inhibition at $89 \%$. Therefore, novel MPAOs containing active triazole rings, thioethers, Schiff bases, and BHT moieties are suggested as potential antioxidants for inhibiting oxidative stress processes and scavenging free radicals, hence, this combination of functions is anticipated to play a vital role in repairing cellular damage, preventing various human diseases and in medical therapeutic applications.
\end{abstract}

Keywords: butylated hydroxytoluene; PASS; 1,2,4-triazole; Schiff base; DPPH assay

\section{Introduction}

Regulation of reducing and oxidizing status is critical for the viability of cell organ functions [1]. Reactive oxygen species (ROS) have a strong disruptive effect on industrial products, such as oils, plastics and rubbers. They exist in different forms, such as hydroxyls (HO•), superoxide anion radicals 
$\left(\mathrm{O}_{2} \bullet-\right)$, peroxyls $(\mathrm{ROO} \bullet)$, alkoxyls $(\mathrm{RO} \bullet)$, and nitric oxides (NO•) [2]. They can potentially cause oxidation in foodstuffs [3], pharmaceuticals [4-6], and petroleum and rubber products [7] via several degradation reactions, both upon heating and during long-term storage. The presence of ROS in biological systems was confirmed around 50 years ago [8].

Inflammation and increased oxidative stress contribute actively to increased pathogenesis of many human diseases due to undesirable processes, such as aging [9], inflammation [10,11] and many others [12-16].

Pharmacological strategies should aim to supplement antioxidant defense systems while antagonizing redox-sensitive signal transduction, which will subsequently lead to improved clinical management of the inflammatory process [17]. Antioxidants also represent a wide class of additives used for food [18], lubricants [19], polymers [20] and paints [21], etc.

Phenolic antioxidants form a significant class of compounds both commercial and biological importance, which serve to inhibit oxidation to counteract the autoxidation reaction of hydrocarbons, unsaturated fatty acids or esters, and other substances [22]. Synthetic antioxidants, particularly phenols that are used as food, polymer, pharmaceutical, and oil additives, include BHT, butylated hydroxyanisole (BHA) and tert-butylhydroquinone [23]. BHT [24] has been approved by FDA since 1954 [23] for use in food packaging. Currently, BHT is the most commonly used antioxidant in foods [25], rubber [7] and pharmaceutical products. Due to its industrial applications, researchers have designed and synthesized a series of BHT derivatives to accelerate the antioxidant discovery process, aiming to expand its applications with a wide range of antioxidant activities to markedly enhance the radical scavenging ability and other physical properties. Accordingly, some rational-design strategies for antioxidants based on BHT structure have been designed and the corresponding target compounds synthesized [26-28].

1,2,4-Triazoles are a class of five membered heterocycles, extensively researched due to their medicinal properties [29,30]. 1,2,4-Triazole-5-thiones are known for their anti-inflammatory [31], COX-2 inhibitor [32], and antimycotic [33] activities. A series of Schiff bases of 3-substituted-1,2, 4-triazo-5-thione have been synthesized and evaluated for their antioxidant activity using the hydrogen peroxide scavenging method [34].

In this study, SAR and rational design approaches were utilized to integrate multiple radical-scavenging activities in designing hybrid compounds with significantly enhanced radical-scavenging capacity. These approaches were verified with PASS training subsets. PASS-predicted antioxidant activities for Schiff base-1,2,4-triazoles bearing BHT moieties were experimentally verified using DPPH assays.

\section{Results and Discussion}

\subsection{SAR and Designing of MPAO}

The design approach for free radical inhibitors involves gathering the useful features of different antioxidant fragments into a single structure. This approach was implemented to increase the antioxidant activities and other physical properties of the well-known antioxidant (BHT) and identify novel MPAOs bearing particular antioxidant fragments that are very important in the introduction of promising MPAO candidates possessing different physical and chemical properties, as illustrated in Figure 1. These features include the following: 

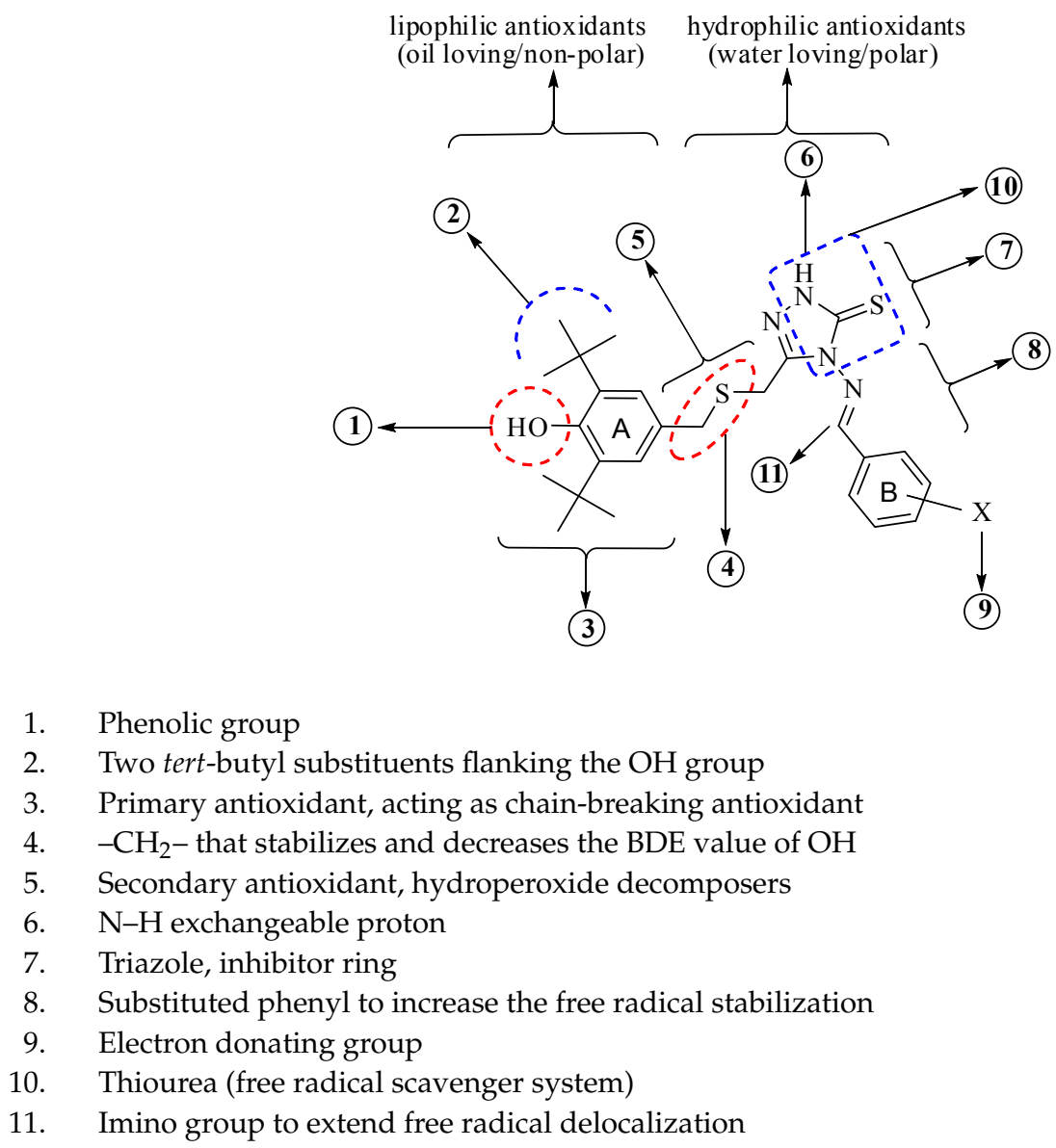

Figure 1. Rational design of Schiff base-1,2,4-triazoles bearing BHT moieties.

\subsection{PASS-Prediction}

PASS tools are constructed to predict over 4000 types of biological activity, including drug and non-drug actions. PASS predictions can be used to recognize the most probable targets at the molecular level [35], with 90\% accuracy [36-39]. It has been reported that PASS predictions can be successfully applied and confirmed by pharmacological research experiments [35,40-42]. PASS results are presented as a list with an appropriate $\mathrm{Pa}$ (compound probability to be active) and $\mathrm{Pi}$ (compound probability to be inactive). Compounds with $\mathrm{Pa}>\mathrm{Pi}$ are assumed to be active. For example, if $\mathrm{Pa}>0.7$, the possibility of discovering the activity in the experiment is high, but in some cases, the compound's structure is analogous to the PASS training set. If $0.5<\mathrm{Pa}<0.7$, the possibility of discovering the activity in the experiment is less, however, the compound's structure is dissimilar to the PASS training set. If $\mathrm{Pa}<0.5$, the possibility of finding the activity in the experiment is even less, but if it is verified, then there is more than $50 \%$ possibility that this structure has not been reported in the context of this particular biological activity, and this might be a valuable lead compound.

The PASS approach has significant limitations: (i) the activity spectrum cannot be predicted for compounds that have no identifier in the PASS training set; and (ii) PASS predictions can only clarify the intrinsic activity of a compound via experiments. In this work PASS was used to predict the biological activities of Schiff base-1,2,4-triazoles bearing BHT moieties to promote the search for high efficiency new MPAOs. The potential antioxidant activities of the designed compounds were predicted based on SAR analysis of the PASS training set from many sources, including publications, patents, databases, and private communications.

Therefore, PASS predicted different antioxidant activities for the synthesized compounds, such as lipid peroxidase inhibition, antioxidant, and free radical scavenging, and BHT, as given in Table 1. Antioxidant activities generated by PASS were validated by DPPH bioassays. 
Table 1. PASS prediction of the synthesized compounds 1, 3-10 and BHT.

\begin{tabular}{|c|c|c|c|c|c|c|c|c|c|c|c|c|c|c|c|c|c|c|c|c|}
\hline \multirow{2}{*}{$\begin{array}{c}\text { Mode of Biological } \\
\text { Activity }\end{array}$} & \multicolumn{2}{|c|}{1} & \multicolumn{2}{|c|}{3} & \multicolumn{2}{|c|}{4} & \multicolumn{2}{|c|}{5} & \multicolumn{2}{|c|}{6} & \multicolumn{2}{|c|}{7} & \multicolumn{2}{|c|}{8} & \multicolumn{2}{|c|}{9} & \multicolumn{2}{|c|}{10} & \multicolumn{2}{|c|}{ BHT } \\
\hline & $\mathbf{P a}$ & $\mathbf{P i}$ & $\mathbf{P a}$ & $\mathbf{P i}$ & $\mathbf{P a}$ & $\mathbf{P i}$ & $\mathbf{P a}$ & $\mathbf{P i}$ & $\mathbf{P a}$ & $\mathbf{P i}$ & $\mathrm{Pa}$ & $\mathbf{P i}$ & $\mathbf{P a}$ & $\mathbf{P i}$ & $\mathrm{Pa}$ & $\mathbf{P i}$ & $\mathrm{Pa}$ & $\mathbf{P i}$ & $\mathbf{P a}$ & $\mathbf{P i}$ \\
\hline Lipid peroxidase inhibitor & 0.44 & 0.02 & 0.71 & 0.00 & 0.52 & 0.01 & 0.46 & 0.02 & 0.38 & 0.03 & 0.40 & 0.03 & 0.36 & 0.04 & 0.34 & 0.05 & 0.24 & 0.09 & 0.72 & 0.005 \\
\hline Antioxidant & 0.41 & 0.01 & 0.41 & 0.01 & 0.29 & 0.02 & 0.31 & 0.02 & 0.30 & 0.02 & 0.29 & 0.02 & 0.26 & 0.03 & 0.27 & 0.02 & 0.25 & 0.03 & 0.58 & 0.005 \\
\hline Free radical scavenger & 0.51 & 0.00 & - & - & 0.14 & 0.13 & 0.17 & 0.09 & - & - & - & - & - & - & - & - & & - & 0.51 & 0.010 \\
\hline Lipoxygenase inhibitor & 0.37 & 0.00 & 0.21 & 0.01 & 0.17 & 0.02 & 0.18 & 0.02 & 0.18 & 0.02 & 0.17 & 0.02 & 0.22 & 0.01 & 0.18 & 0.02 & 0.16 & 0.02 & 0.56 & 0.004 \\
\hline 5-Lipoxygenase inhibitor & 0.28 & 0.00 & 0.13 & 0.01 & 0.11 & 0.02 & 0.11 & 0.02 & 0.18 & 0.02 & 0.10 & 0.02 & 0.14 & 0.01 & 0.11 & 0.02 & 0.10 & 0.02 & 0.47 & 0.004 \\
\hline
\end{tabular}




\subsection{Synthesis}

The synthesis of the designed compounds $\mathbf{3 - 1 0}$ is outlined in Scheme 1. 2-(3,5-di-tert-Butyl-4-hydroxybenzylthio)acetic acid (1) and corresponding acid hydrazide 2 were synthesized as previously described [26]. The 4-amino-1,2,4-triazole system is a heterocyclic organic compound that consists of a 1,2,4-triazole substituted with an amino group. A synthetic approach to compound 3 is outlined in Scheme 1. The most common synthetic approach reported for the preparation of 4-amino-1,2,4-triazole rings is via the formation of potassium dithiocarbazinate, which is then reacted with hydrazine hydrate in an aqueous solution (Scheme 1, Method-A) [43,44]. However, in our hands, the desired product was not obtained when this method was employed. It is believed that the reaction product underwent hydrolysis, resulting in a mixture of products being obtained according to TLC.

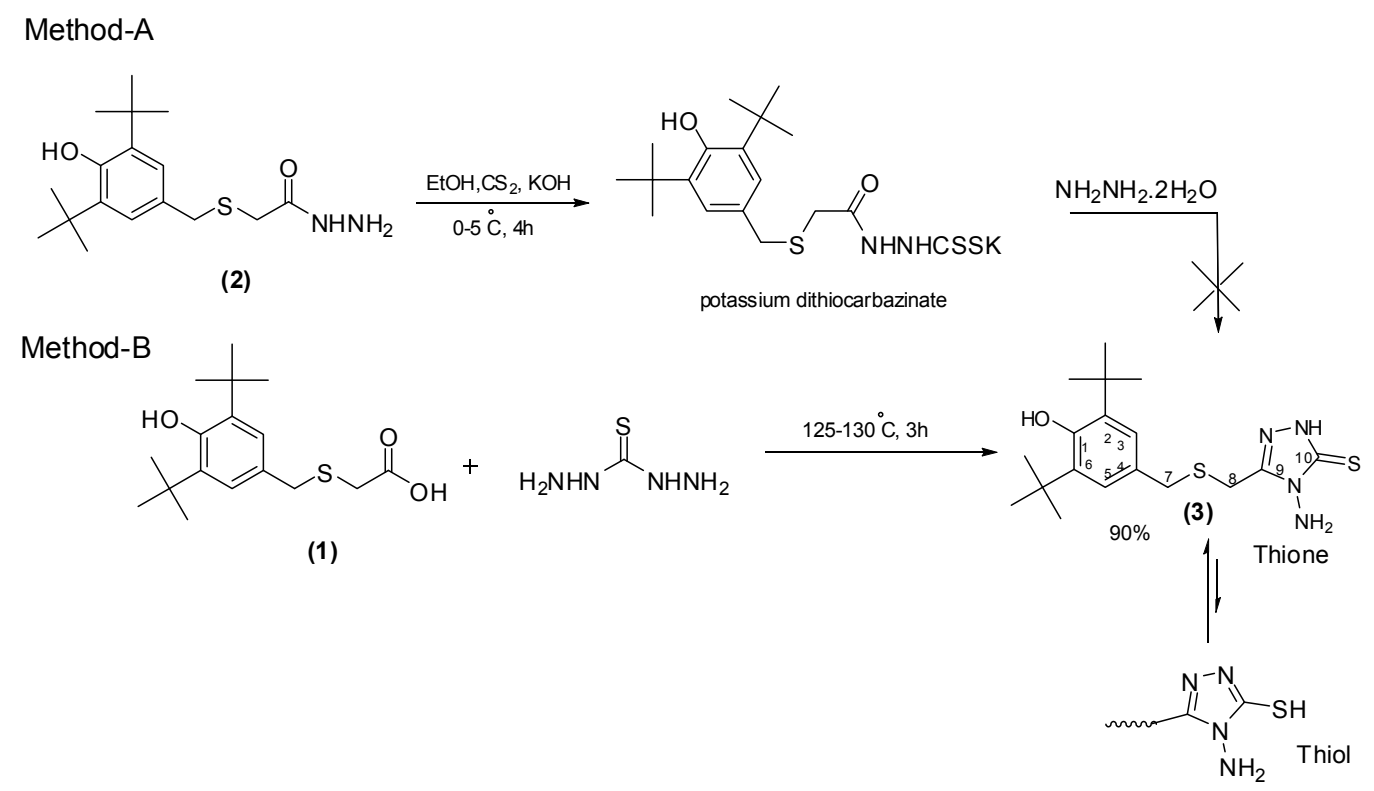

Scheme 1. Synthetic scheme for the formation of 4-amino-3-((3,5-di-tert-butyl-4-hydroxybenzylthio) methyl)-1H-1,2,4-triazole-5(4H)-thione (3).

We then attempted a different method (Scheme 1, Method-B) by fusing compound 1 with thiocarbohydrazide at different mole ratios, as well as different temperature ranges. The results are summarized in Table 2.

Table 2. Preparation of 4-amino-3-((3,5-di-tert-butyl-4-hydroxybenzylthio)methyl)-1H-1,2, 4-triazole-5(4H)-thione (3).

\begin{tabular}{cccccc}
\hline Entry & Compound 1 Mole & Thiocarbohydrazide Mole & Time $\mathbf{h}$ & Temperature ${ }^{\circ} \mathbf{C}$ & Yield (\%) \\
\hline 1 & 1 & 1 & 3 & $90-120$ & 24 \\
2 & 1 & 1.25 & 3 & $125-130$ & 70 \\
3 & 1 & 1.25 & 3 & $155-160$ & 45 \\
4 & 1 & 1.5 & 3 & $125-130$ & 90 \\
5 & 1 & 2 & 3 & $125-130$ & 90 \\
6 & 1 & 1.5 & 3 & $145-150$ & 65 \\
\hline
\end{tabular}

Carrying out the reaction with a mole ratio of 1:1 of compound 1 to thiocarbohydrazide (entry 1 ) resulted in a very low yield (24\%). Altering the mole ratio of $\mathbf{1}$ to thiocarbohydrazide to 1:1.25 (entry 2) resulted in a much higher yield (70\%). Increasing the reaction temperature to $155-160{ }^{\circ} \mathrm{C}$ resulted in a decrease in the yield to only $45 \%$ (entry 3). When a 1:1.5 mole ratio was used (entry 4 ), a satisfactory 
yield of $90 \%$ was obtained. However, if the 1:2 mole ratio was used, the yield did not increase apparently (entry 5), while increasing the reaction temperature in entry 4 decreased the yield (entry 6 ).

Formation of compounds 3-10 was confirmed by recording their IR, NMR, high-resolution mass spectra. The IR spectra of compounds 3-10 showed absorption bands at 3639, (3192, 3269), 1629, and $1231 \mathrm{~cm}^{-1}$ due to the $\mathrm{O}-\mathrm{H}, \mathrm{N}-\mathrm{H}, \mathrm{C}=\mathrm{N}$ and $\mathrm{C}=\mathrm{S}$ groups, respectively. In the ${ }^{1} \mathrm{H}-\mathrm{NMR}$ spectrum of 3 , we find a sharp singlet peak at $1.40 \mathrm{ppm}$, due to the eighteen equivalent methyl protons of 2- $\mathrm{C}\left(\mathrm{CH}_{3}\right)_{3}$. Thioether group H-7 and $\mathrm{H}-8$ exhibited two singlets $\left(\mathrm{A}_{2}\right.$ system) at $3.63 \mathrm{ppm}$ and $3.64 \mathrm{ppm}$, respectively. The singlet at $4.74 \mathrm{ppm}$, with the integration of two protons, corresponds to the $-\mathrm{NH}_{2}$ group. The singlet peak at $5.18 \mathrm{ppm}$ is attributed to the $\mathrm{O}-\mathrm{H}$ of the hindered phenol. A singlet peak at $7.11 \mathrm{ppm}$ with the integration of two protons was assigned to the two symmetrical aromatic ring protons, $\mathrm{H}-3$ and $\mathrm{H}-5$. The NH-proton of the triazole ring resonated as a broad band at $11.38 \mathrm{ppm}$, which agrees with the presence of the thione form (see the ${ }^{1} \mathrm{H}-\mathrm{NMR}$ spectrum of 3 in the Supplementary Materials). The ${ }^{13} \mathrm{C}-\mathrm{NMR}$ spectra of 3 confirmed the presence of two sp ${ }^{2}$ methines (C-3 and C-5), eight quaternary carbons. C-2 and C-6 are symmetrical, and attached to di-tert-butyl groups. The quaternary carbons C-9 and C-10 appeared in the region at 150.42 and $167.06 \mathrm{ppm}$, respectively (see the ${ }^{13} \mathrm{C}-\mathrm{NMR}$ spectrum of 3 in the Supplementary Materials).

The condensation reaction of 3 , with substituted aromatic aldehydes in the presence of PTSA in $\mathrm{DMF}$ at RT, resulted in a good yields of products, ranging from $66 \%-85 \%$ (Scheme 2 ).

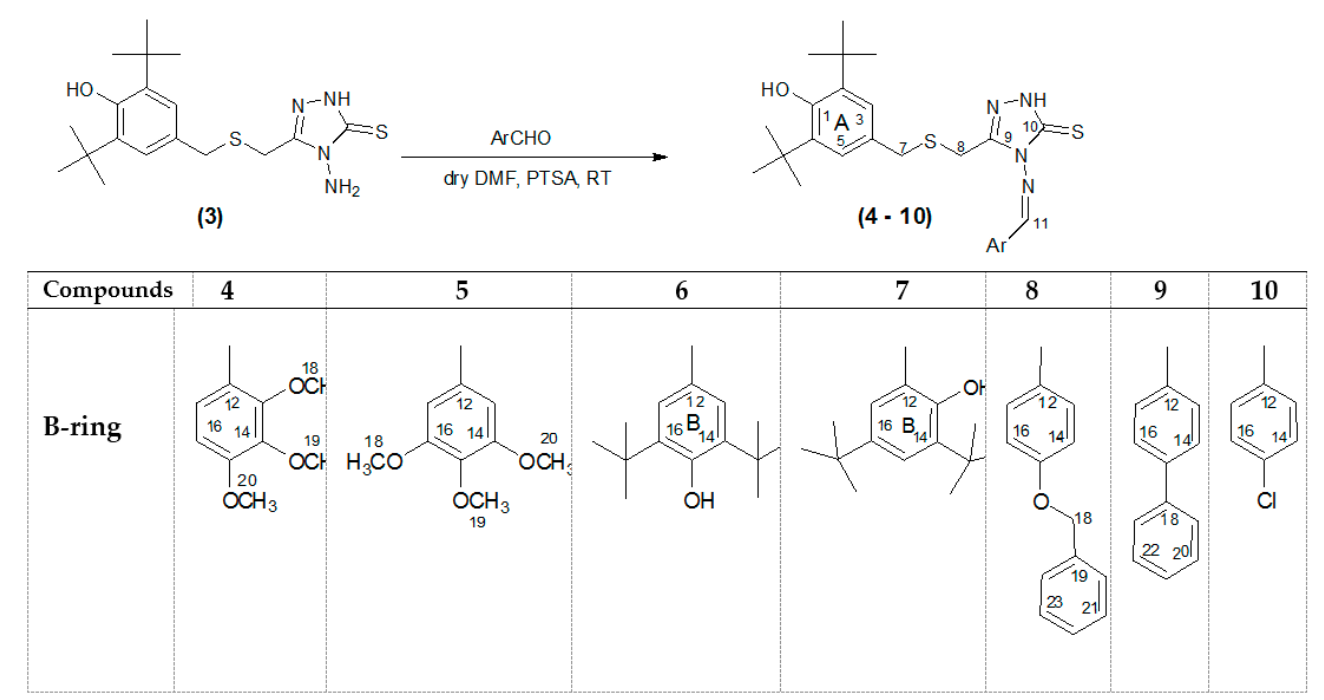

Scheme 2. Synthetic scheme for the formation of 4-(substituted benzylideneamino)-3((3,5-di-tert-butyl-4-hydroxybenzyl thio)methyl)-1H-1,2,4-triazole-5(4H)-thiones 4-10.

The ${ }^{1} \mathrm{H}-\mathrm{NMR}$ spectra of $\mathbf{4}-\mathbf{1 0}$ showed a singlet peak between 1.41-1.42 ppm, due to the eighteen equivalent protons of $2-\mathrm{C}\left(\mathrm{CH}_{3}\right)_{3}$, while the thioether group $\mathrm{H}-7$ and $\mathrm{H}-8$ exhibits two very close singlets in the region 3.70-3.72 and 3.65-3.75 ppm, respectively. Two protons appeared as a singlet between 7.09-7.12 ppm, which is assigned to the two symmetrical aromatic ring protons H-3 and $\mathrm{H}-5$. The hydroxyl group link to $\mathrm{C}-1$ of all the synthesized Schiff base-1,2,4-triazoles show a singlet peak in the region 5.15-5.17 ppm, due to the free $\mathrm{O}-\mathrm{H}$, which is flanked by two tert-butyl groups, while only 6 and 7 showed other phenolic hydroxyl functional groups (see the ${ }^{1} \mathrm{H}-\mathrm{NMR}$ spectra of 4-10 in the Supplementary Materials). In 6, a singlet at $5.70 \mathrm{ppm}$ was assigned to the phenolic $\mathrm{OH}$ linked to C-15, which was also flanked by two tert-butyl groups. In contrast to 6 , the phenolic $\mathrm{OH}$ of 7, which is linked to C-13, is significantly deshielded to $10.61 \mathrm{ppm}$, due to its lesser steric effect than that of an $\mathrm{O}-\mathrm{H}$ between the two bulky groups, which supports the fact that the azomethine bond has an E-configuration, while the hydroxy group bears a hydrogen atom, which is a donor in an intramolecular $\mathrm{H}$ bond to the azomethine nitrogen atom [45] (Figure 2). 


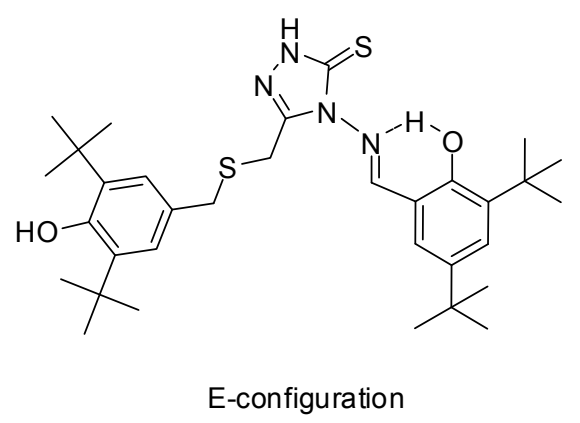

Figure 2. Proposed intra-molecular hydrogen bonding of 7.

Schiff base-1,2,4-triazoles 4-10 show singlet peaks in the region between 10.60 to $10.33 \mathrm{ppm}$, due to a $\mathrm{NH}$, indicating the presence of a triazole ring, while the other singlets between 9.87-10.43 ppm were attributed to $\mathrm{CH}=\mathrm{N}$, and the disappearance of the $\mathrm{NH}_{2}$ protons of 3 further confirmed the presence of a five-membered ring, as well as an imine system present within one molecule. The ${ }^{13} \mathrm{C}-\mathrm{NMR}$ spectra of 4-10 indicated the presence of one $\mathrm{sp}^{2}$ methine shifted downfield between 159.07-168.69 ppm. The complete assignments for the ${ }^{13} \mathrm{C}-\mathrm{NMR}$ spectra of compounds $\mathbf{4 - 1 0}$ are illustrated in the Supplementary Materials.

\subsection{In Vitro DPPH Radical Scavenging Activity}

To verify the antioxidant activity of the designed MPAO, an in vitro DPPH antioxidant assay was used. Schiff base-1,2,4-triazoles 4-10 were examined for their antioxidant potency using a well-known standard antioxidant, BHT. In its radical form, DPPH• absorbs at $570 \mathrm{~nm}$. DPPH• is scavenged by an antioxidant through hydrogen atom transfer reactions to form a stable DPPH molecule, resulting in a color change from purple to yellow [46,47].

The antioxidant activities of various phenolic compounds are determined by monitoring the concentration of the highly coloured and stable radical DPPH•, which has an unpaired valence electron at one of the nitrogen bridge in the context of spectrometry [46,47]. The ability of DPPH to capture free radicals could be due to the delocalization of the unpaired electron over the DPPH structure [48]. The delocalization of the unpaired electron over the DPPH structure showed its ability to react with different free radicals at three different stages: (i) at the $p$-position on the phenyl ring; (ii) the nitrogen-centered radical and (iii) on the picryl ring [48].

In the DPPH free radical assay, antioxidant efficiency is measured at ambient temperature, thus eliminating the risk of thermal degradation of the molecules being tested [49]. However, the DPPH method also has its limitations, particularly since the nitrogen-centered radical portion of the DPPH structure is accessible only to smaller molecules. Larger molecules may have limited access, due to steric hindrance [50]. Steric accessibility of an antioxidant compound determines the type of reaction mechanisms [51]. Small molecules that are exposed are in better contact with the nitrogen-centered radical site, showing higher antioxidant activity. Since DPPH• is a stable nitrogen radical, unlike the highly reactive and transient peroxyl radicals, which is involved in lipid peroxidation, many phenolic antioxidants that react quickly with peroxyl radicals may react slowly with, or may even be inert to DPPH•, due to the steric inaccessibility effects [51]. Bondet et al. [49] reported that most phenolic antioxidants slowly react with DPPH, reaching steady state in 1-6 h, or longer. It was also reported that the reaction of DPPH• is reversible with some phenols. This would result in false low readings for antioxidant capacity of samples containing phenols [49]. Furthermore, a color interference of DPPH with samples that contain anthocyanins led to the underestimation of the antioxidant activity [52].

Compounds studied in this work were designed based-on antioxidant activity of the BHT moiety. BHT is one of the control groups in the experiment, and it would therefore be useful to understand the plausible mechanisms involving BHT and DPPH•. The reaction mechanism between BHT and DPPH 
radical is believed to follow three possible pathways, as demonstrated in Scheme 3 [49]. The reaction of BHT with DPPH• form a BHT radical species A, which can form compound $\mathbf{B}$ via the donation of a second hydrogen atom, or dimerizing to form bis-BHT, $\mathbf{C}$, which presumably reacted for the second time with $\mathrm{DPPH} \bullet$ to produce the bi-quinonoid compound $\mathbf{D}$ [53].<smiles>Cc1cc(C(C)(C)C)c(O)c(C(C)(C)C)c1</smiles>

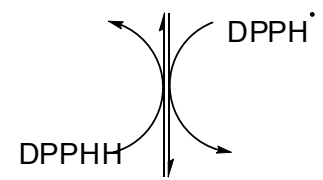<smiles>Cc1cc(C(C)(C)C)c([O-])c(C(C)(C)C)c1</smiles>

A

BHT

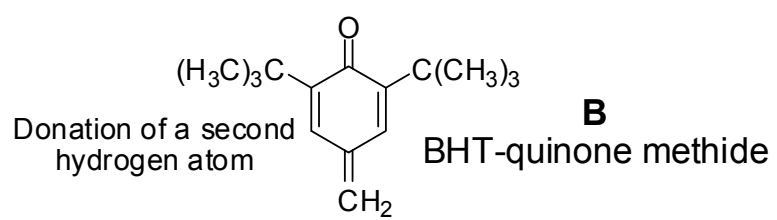

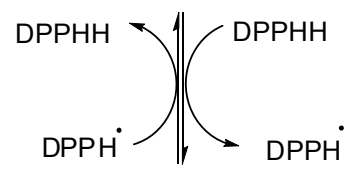<smiles>CCc1cc(C(C)(C)C)c(O)c(C(C)(C)C)c1</smiles>

Dimerization Complexation

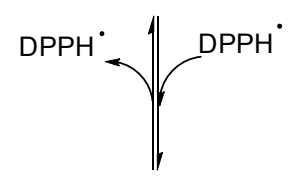<smiles>C1CCCC1</smiles><smiles>C1CCCCC1</smiles>
Bis-BHT<smiles>CC(C)(C)c1cc(Cc2ccccc2)cc(C(C)(C)C)c1O</smiles>

Bi-quinonoid<smiles>CC(C)(C)C1=CC(=CC=C2C=C(C(C)(C)C)C(=O)C(C(C)(C)C)=C2)C=C(C(C)(C)C)C1=O</smiles>

Scheme 3. Proposed mechanism for BHT/DPPH• reaction.

Most synthesized Schiff base-1,2,4-triazoles that were tested significantly inhibited the DPPH• levels compared to the standard antioxidant (BHT) used in the study (Table 3). This might be due to the presence of more than one antioxidant functional group within the structure of the Schiff base-1,2,4-triazoles. Our synthesized molecules have similar active groups, but different antioxidant activity against DPPH radicals, due to the different substituents attached to the B ring. Therefore, the main source of antioxidant activity of compounds $\mathbf{4 - 1 0}$ are strongly attributed to the following antioxidant functional groups presented in our design. 
Table 3. $\mathrm{IC}_{50}$ values and maximum inhibition of activity at $100 \mu \mathrm{M}$ of the DPPH radical scavenging and lipid peroxidation inhibition assays.

\begin{tabular}{|c|c|c|}
\hline Compound & DPPH IC ${ }_{50}{ }^{a}$ Values $(\mu \mathrm{M}) \pm$ S.E.M $^{b}$ & Radical Scavenging Max. Inhibition $\% \pm$ S.E.M \\
\hline 4 & $64.04 \pm 0.32$ & $68.13 \pm 0.27$ \\
\hline 5 & $58.26 \pm 0.63$ & $74.32 \pm 0.14$ \\
\hline 6 & $46.13 \pm 0.31$ & $89.52 \pm 0.09$ \\
\hline 7 & $52.80 \pm 0.58$ & $79.61 \pm 0.23$ \\
\hline 8 & $67.59 \pm 0.27$ & $66.72 \pm 0.15$ \\
\hline 9 & $68.04 \pm 0.25$ & $63.37 \pm 0.13$ \\
\hline 10 & $72.16 \pm 0.46$ & $57.18 \pm 0.21$ \\
\hline BHT & $>100^{\mathrm{c}}$ & $25.23 \pm 0.17$ \\
\hline
\end{tabular}

${ }^{\mathrm{a}} \mathrm{IC}_{50}: 50 \%$ effective concentration; ${ }^{\mathrm{b}}$ S.E.M: standard error of the mean; ${ }^{\mathrm{c}}$ did not reach $50 \%$ inhibition.

\subsubsection{BHT Moiety (Primary Antioxidant)}

It has been reported that substituents, such as tert-butyl on the ortho and para positions increase the antioxidant activity of phenols [54] due to the lowering of the O-H bond dissociation energy (BDE) [55] and the stabilization of the phenoxyl radical by inductive and hyperconjugative effects. This can be rationalized on the basis of the transition state shown in Figure 3, where there is a partial separation of charge between the alkylperoxyl and aromatic ring and partial delocalization of the electron in the $\pi$-bond. Placing electron-releasing group that can delocalize unpaired electrons in $R_{1}, R_{2}$, and $X$ will decrease the transition state energy [56,57].

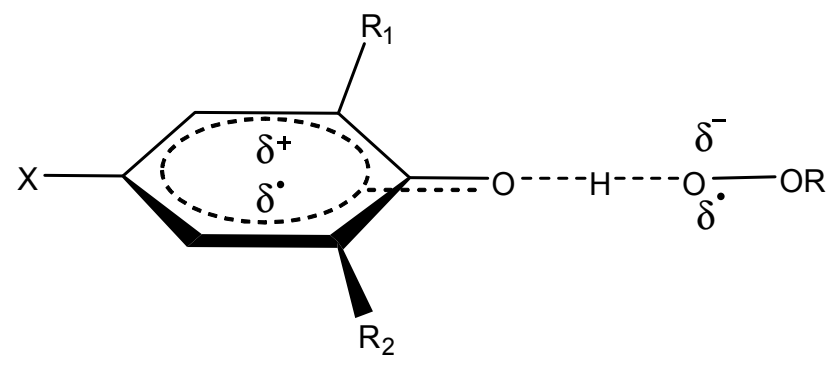

Figure 3. Transition state of hydrogen abstraction by ROS.

Furthermore, substituents at the o-position would cause the steric hindrance to reduce pro-oxidation reactions [58,59], as shown in Figure 4.

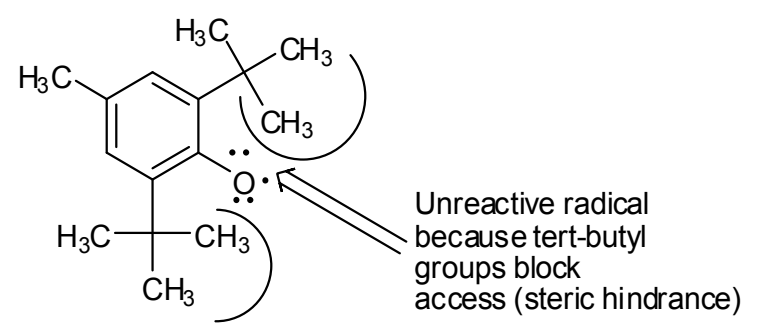

BHT radical-ends chain reaction

Figure 4. Steric hindrance effects on stabilization of phenoxyl radical [57].

Thus, the reactions of BHT moiety of A ring with DPPH• led to hydrogen abstraction from the O-H bond via delocalization of the oxygen electron pair over the aromatic ring, forming stable phenoxyl radical. Therefore, the BHT moiety of the A ring was chosen to be a chain-breaking antioxidant unit in 
the designs of MPAO Figure 1. This phenomenon could improve the antioxidant activity of our newly designed molecules, causing it to perform at a similar level to the standard antioxidant agent (BHT).

\subsubsection{Thioether Function (Secondary Antioxidant)}

Thioethers are frequently referred to as hydroperoxide decomposers, and are therefore classified as secondary antioxidants [59]. Thioethers undergo redox reactions with hydroperoxides to form non-radical stable products [56,60]. Sulfur-containing phenols are of particular interest, as they can behave synergistically as chain-breaking and preventive antioxidants by decomposing hydroperoxides to the corresponding alcohols via nucleophilic attack of sulfur on oxygen [61]. Moreover, sulfur is considered to be more effective than oxygen at stabilizing a neighbouring radical center due to better lone-pair interaction with the carbon $p$-orbital [62]. Sulfur containing phenols might be better antioxidants than the phenols containing oxygen substituents at the para position to the phenolic group. Therefore, the designed compounds contain thioether antioxidant-bridge as its linkage between the BHT moiety (A ring) and other antioxidants, as well as its functionalities.

\subsubsection{Triazole-5-thione Ring}

Triazole-5-thione is present as a planar molecule in the thione form (I) over the thiol form (II) (Figure 5). The sulfur atom was the atom with the largest electron density in the molecule [63]. Thus, the chemical behavior of the system towards free radicals would depend on the tautomeric form present in the reaction, assuming that the sulfur atom is involved with the reactive site. It was found that the triazole-5-thione derivatives are relatively more active than the derivatives of thiadiazole, which is due to the presence of thiourea system in triazole ring [57,64-66].

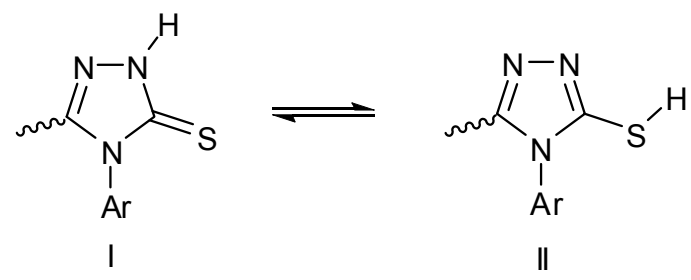

Figure 5. Thione I and thiol II tautomers of 4-amino-1,2,4-triazol-5-thione.

Therefore, the presence of triazole-5-thione in our designed compounds could provide a new series of antioxidants for disease prevention and treatment in the field of oxidative stress.

\subsubsection{Effect of Ring B Substituents on Antioxidant Activity}

The only difference between the designed Schiff base-1,2,4-triazoles $\mathbf{4 - 1 0}$ is the nature of the substituents attached to their $\mathbf{B}$ rings. It has been reported that the electron delocalization across the aromatic imine (B ring) and triazole-5-thione attached directly to the N-4 of ring is not an option [66], therefore; the substituents on the phenyl B ring and its corresponding imine group, as an aromatic system, are influential upon the radical-scavenging effects, due to their ability to extend the delocalization of free radical and enhance antioxidative abilities. However, according to the nature of their substituents on the $\mathbf{B}$ ring, the antioxidant activities of the Schiff base-1,2,4-triazoles synthesized in this study can be divided into three classes:

The first class consists of compounds 6 and 7, which show significant inhibition of DPPH radicals compared to the BHT used in this study as a reference. As shown in Table 3, Schiff base-1,2,4-triazoles 6 and 7 exhibited strong scavenging effect on $\mathrm{DPPH}$, with an $\mathrm{IC}_{50}$ value of $46.13 \pm 0.31$ (inhibition $=89.52 \%$ ) and $\mathrm{IC}_{50}$ value of $52.80 \pm 0.58$ (inhibition $=79.61 \% \pm 0.23 \%$ ) $\mu \mathrm{M} / \mathrm{mL}$, respectively, which are thrice better than the BHT with \% inhibition of 25.23. At their B rings, these compounds contain a phenolic hydroxyl group at the para (compound 6) and ortho (compound 7) positions to 
the imine group and the electron donating groups (EDGs) at the ortho-positions to their hydroxyl groups. The high activity can be explained by the resonance-based stabilizing effects of the EDG and the hydrazone on the phenoxy radical at the $\mathbf{B}$ ring. The higher activity of compound $\mathbf{6}$ is due to the enhanced steric hindrance effect provided by the two ortho-tertiary butyl groups, which stabilize the phenolic antioxidant radical. In compound 7, it is believed that an intramolecular hydrogen bond between the phenolic hydrogen with the imine nitrogen disfavors the DPPH scavenging activity of 7, owing to the enhanced binding of the phenolic hydrogen atom [47], as displayed in Figure 2. It was found that the $\mathrm{H}$-bond stabilizes phenols, therefore, the energy required to extract the hydrogen atom from the $\mathrm{O}-\mathrm{H}$ is larger than in the non $\mathrm{H}$-bonded phenols [67]. Thus, the $\mathrm{OH}$ group of compound 7 exhibited strong hydrogen bonds with the imine group (Figure 2), the $\mathrm{O}-\mathrm{H}$, and the $\mathrm{N}$ atom of $\mathrm{C}=\mathrm{N}$, which could in theory increase the BDE by stabilizing the amine form, making the approach of peroxyl radicals to the $\mathrm{O}-\mathrm{H}$ group more difficult for steric reasons.

The second class consists of compounds 4 and 5, showing significant levels of inhibition of DPPH radical compared to the standard antioxidant (BHT), yielding a DPPH• inhibition of $68.13 \%$ for 4 and $74.32 \%$ for 5 , while BHT resulted in a value of $25.23 \%$. Neither of these compounds contains a phenolic hydroxyl group on the B ring, but they may increase the phenyl ring stabilization, due to formation resonance of stabilized radicals [6].

The third class covers compounds 8-10. All of these compounds contain different substituents at the para position to the imine group. The DPPH radical scavenging activity for this class is substantially lower than that of the first and second classes, but better than the standard antioxidant (BHT), due to their resonance-based stabilizing effects [68].

\section{Materials and Methods}

\subsection{General Information}

All materials and solvents were obtained from Sigma-Aldrich (St. Louis, MO, USA). Melting points were determined on a MEL-TEMP II melting point instrument (Barnstead/Thermolyne Corp, North Sioux, SD, USA). IR spectra were recorded on a RX1FT-IR spectrometer (Perkin-Elmer, Waltham, MA, USA). The ${ }^{1} \mathrm{H}-(400 \mathrm{MHz})$ and ${ }^{13} \mathrm{C}-\mathrm{NMR}(100 \mathrm{MHz})$ spectra were recorded on a $400 \mathrm{MHz}$ FT-NMR (JEOL Ltd., Tokyo, Japan) using $\mathrm{CDCl}_{3}$ as a solvent and tetramethylsilane as an internal standard. The abbreviations $\mathrm{s}=$ singlet, $\mathrm{d}=$ doublet, $\mathrm{t}=$ triplet, $\mathrm{q}=$ quadruplet, $\mathrm{m}=$ multiplet and $\mathrm{bs}=$ broad signal were used throughout. HR-mass spectra (ESI) were obtained with a Finnigan MAT95XL mass spectrometer at $70 \mathrm{eV}$ (Thermo Fisher Scientific, Waltham, MA, USA). UV-visible spectra were recorded on a model UV-1650PC UV-visible spectrophotometer (Shimadzu Europe, Duisburg, Germany). The Supplementary Data section reports the ${ }^{1} \mathrm{H}-\mathrm{NMR}$ (Figures S1-S8) and ${ }^{13} \mathrm{C}-\mathrm{NMR}$ (Figures S9 and S10) spectral data of compounds 3-10.

3.2. Synthesis of 4-Amino-3-((3,5-di-tert-butyl-4-hydroxybenzylthio)methyl)-1H-1,2,4-triazole-5(4H)-thione (3)

\subsubsection{Method-A}

Potassium Dithiocarbazinate Method

Potassium hydroxide ( $2 \mathrm{mmol}, 0.11 \mathrm{~g}$ ) was dissolved in absolute ethanol (15 $\mathrm{mL})$. S-(3,5-di-tert-butyl-4-hydroxybenzyl)thioglycolic acid hydrazide $(2,1.5 \mathrm{mmol}, 0.48 \mathrm{~g})$ was added and the solution was cooled in ice. To this mixture, carbon disulfide ( $2 \mathrm{mmol}, 0.15 \mathrm{~g})$ was added in small portions with constant stirring. The reaction mixture was agitated continuously for a period of $4 \mathrm{~h}$ at room temperature. It was then diluted with anhydrous ether. The precipitated potassium dithiocarbazinate was collected by filtration and dried under vacuum. The potassium salt thus obtained was in yellow solid, yield $63 \%(0.55 \mathrm{~g})$ and was used in the next step without further purification. 
A suspension of potassium dithiocarbazinate $(0.57 \mathrm{mmol}, 0.25 \mathrm{~g})$ in water $(5 \mathrm{~mL})$ and hydrazine hydrate $(1.71 \mathrm{mmol}, 0.08 \mathrm{~mL})$ was stirred for $1 \mathrm{~h}$. The color of the reaction changed to green with the evolution of hydrogen sulfide gas (lead acetate paper and odor). A homogenous reaction mixture was obtained during the reaction process. The reaction mixture was diluted with distilled water $(15 \mathrm{~mL})$. On acidification with dilute hydrochloric acid, no triazole 3 was isolated.

\subsubsection{Method-B}

\section{Fusion Reaction Method}

S-(3,5-di-tert-butyl-4-hydroxybenzyl)thioglycolic acid $(\mathbf{1} ; 3.10 \mathrm{~g}, 10 \mathrm{mmol})$ in a flat bottomed flask was heated in oil bath $\left(100-120^{\circ} \mathrm{C}\right)$ until the acid melted. Thiocarbohydrazide $(1.60 \mathrm{~g}, 15 \mathrm{mmol})$ was added with stirring. The mixture was maintained at $\left(125-130{ }^{\circ} \mathrm{C}\right)$ for $1 \mathrm{~h}$. Then it was allowed to cool to room temperature and treated with dilute sodium bicarbonate solution in order to remove any unreacted acid. The crude was dissolved in chloroform then filtered to remove unreacted thiocarbohydrazide. The crude product, obtained after concentration under reduced pressure. The product was recrystallised from ethanol to give $3.42 \mathrm{~g}$ of white solid $(90 \%)$. Mp $192-194{ }^{\circ} \mathrm{C}$. IR (KBr), $\mathrm{cm}^{-1}: v=3639$ (free $\left.\mathrm{OH}, \mathrm{BHP}\right), 3192,3269(\mathrm{NH}), 2870-2958(\mathrm{C}-\mathrm{H}$ of $t-\mathrm{Bu}), 1629(\mathrm{C}=\mathrm{N})$, 1231 (C=S). ${ }^{1} \mathrm{H}-\mathrm{NMR} \delta$, ppm (Figure S1): 1.40 (s, 18H, $2 \times t$-Bu), 3.63 (s, 2H, H-7), $3.64(2 \mathrm{H}, \mathrm{H}-8), 4.74$ $\left(2 \mathrm{H}, \mathrm{NH}_{2}\right), 5.18(1 \mathrm{H}, \mathrm{OH}, \mathrm{BHP}), 7.11(\mathrm{~s}, 2 \mathrm{H}, \mathrm{H}-3, \mathrm{H}-5), 11.38\left(1 \mathrm{H}, \mathrm{NH}\right.$, triazole). ${ }^{13} \mathrm{C}-\mathrm{NMR} \delta, \mathrm{ppm}$ (Figure S9): $24.07(1 \mathrm{C}, \mathrm{C}-8), 30.38\left(6 \mathrm{C}, 2 \times-\mathrm{C}\left(\mathrm{CH}_{3}\right)_{3}, 34.45\left(2 \mathrm{C}, 2 \times-\mathrm{C}\left(\mathrm{CH}_{3}\right)_{3}\right), 36.26(1 \mathrm{C}, \mathrm{C}-7), 125.99\right.$ (2C, C-3, C-5), 127.19 (1C, C-4), 136.21 (2C, C-2, C-6), 150.42 (1C, C-9), 153.21 (1C, C-1), 167.06 (1C, C-10). HREIMS $m / z 380.1720[\mathrm{M}]^{+}$(calcd for $\mathrm{C}_{18} \mathrm{H}_{28} \mathrm{ON}_{4} \mathrm{~S}_{2} 380.1705$ ).

\subsection{General Procedure for the Synthesis of 4-(Substituted benzylideneamino)-3-(3,5-di-tert-butyl-4 -hydroxybenzyl thio)methyl)-1H-1,2,4-triazole-5(4H)-thiones 4-10}

Compound 3 ( $0.63 \mathrm{mmol}, 0.24 \mathrm{~g}$ ) in DMF $(5 \mathrm{~mL})$ was added the appropriate aldehyde $(0.63 \mathrm{mmol})$. A little bit of PTSA was added as a catalyst and the reaction mixture was stirred under nitrogen gas at room temperature for $3 \mathrm{~h}$. The mixture was poured into ice-water $(250 \mathrm{~mL})$ with stirring for $3 \mathrm{~h}$. The precipitated solid was filtered off, washed with water to remove the acid catalyst and solvent, dried under vacuum and recrystallized from appropriate solvent.

3-((3,5-Di-tert-butyl-4-hydroxybenzylthio)methyl)-4-(2,3,4-trimethoxybenzylideneamino)-1H-1,2,4-triazole5(4H)-thione (4). Prepared from 2,3,4-trimethoxybenzaldehyde (0.63 mmol, $0.123 \mathrm{~g})$, and recrystallized from 5:1 methanol-water to give $0.26 \mathrm{~g}$ of white solid $(73 \%)$. Mp $161-163{ }^{\circ} \mathrm{C}$. IR $(\mathrm{KBr}), \mathrm{cm}^{-1}: v=3641$ (free OH, BHP), 2908-3048 (C-H of $\left.\mathrm{CH}_{3}\right), 1589(\mathrm{C}=\mathrm{N}), 1230(\mathrm{C}=\mathrm{S}) .{ }^{1} \mathrm{H}-\mathrm{NMR} \delta$, ppm (Figure S2): $1.41(\mathrm{~s}, 18 \mathrm{H}, 2 \times t-\mathrm{Bu}), 3.71(\mathrm{~s}, 4 \mathrm{H}, \mathrm{H}-7, \mathrm{H}-8), 3.88\left(3 \mathrm{H}, \mathrm{H}-20,-\mathrm{OCH}_{3}\right), 3.922\left(3 \mathrm{H}, \mathrm{H}-18,-\mathrm{OCH}_{3}\right)$, $4.00\left(3 \mathrm{H}, \mathrm{H}-19,-\mathrm{OCH}_{3}\right), 5.16(1 \mathrm{H}, \mathrm{OH}, \mathrm{BHP}), 6.75(\mathrm{~d}, 1 \mathrm{H}, \mathrm{H}-17, \mathrm{~J}=8.75 \mathrm{~Hz}), 7.10$ (s, 2H, H-3, H-5), $7.78(\mathrm{~d}, 1 \mathrm{H}, \mathrm{H}-16, J=8.75 \mathrm{~Hz}), 10.30(1 \mathrm{H}, \mathrm{C}-11), 11.04(1 \mathrm{H}, \mathrm{NH}) .{ }^{13} \mathrm{C}-\mathrm{NMR} \delta, \mathrm{ppm}$ (Figure S10) : $24.39(1 \mathrm{C}, \mathrm{C}-8), 30.36\left(6 \mathrm{C}, 2 \times-\mathrm{C}\left(\mathrm{CH}_{3}\right)_{3}, 34.42\left(2 \mathrm{C}, 2 \times-\mathrm{C}\left(\mathrm{CH}_{3}\right)_{3}\right), 36.53(1 \mathrm{C}, \mathrm{C}-7), 56.28(1 \mathrm{C}, \mathrm{C}-18\right.$, $\left.-\mathrm{OCH}_{3}\right), 61.12\left(1 \mathrm{C}, \mathrm{C}-20,-\mathrm{OCH}_{3}\right), 62.56$ (1C, C-19, $\left.-\mathrm{OCH}_{3}\right), 108.10$ (1C, C-17), 119.09 (1C, C-12), 122.42 (1C, C-16), 126.02 (2C, C-3, C-5), 127.44 (1C, C-4), 136.11 (2C, C-2, C-6), 142.13 (1C, C-15), 149.98 (1C, C-9), 153.14 (1C, C-1), 155.23 (1C, C-14), 157.74 (1C, C-13), 159.07 (1C, C-11), 162.68 (1C, C-10). HREIMS $m / z 558.2336[\mathrm{M}]^{+}$(calcd for $\mathrm{C}_{28} \mathrm{H}_{38} \mathrm{O}_{4} \mathrm{~N}_{4} \mathrm{~S}_{2}$ 558.2334).

3-((3,5-Di-tert-Butyl-4-hydroxybenzylthio)methyl)-4-(3,4,5-trimethoxybenzylideneamino)-1H-1,2,4-triazole5(4H)-thione (5). Prepared from 3,4,5-trimethoxybenzaldehyde $(0.63 \mathrm{mmol}, 0.123 \mathrm{gm})$, and recrystallized from 5:1 methanol-water to give $0.27 \mathrm{gm}$ of white solid $(76 \%)$. Mp $158-160^{\circ} \mathrm{C}$. IR (KBr), $\mathrm{cm}^{-1}: v=3631$, 3606 (free OH, BHP), $3447(\mathrm{NH}), 2840-2957\left(\mathrm{C}-\mathrm{H}\right.$ of $\left.\mathrm{CH}_{3}\right), 1608(\mathrm{C}=\mathrm{N}), 1240(\mathrm{C}=\mathrm{S}) .{ }^{1} \mathrm{H}-\mathrm{NMR} \delta, \mathrm{ppm}$ (Figure S3): 1.40 (s, 18H, $2 \times t-\mathrm{Bu}), 3.72(\mathrm{~s}, 2 \mathrm{H}, \mathrm{H}-7), 3.73(2 \mathrm{H}, \mathrm{H}-8), 3.90\left(6 \mathrm{H}, \mathrm{H}-18, \mathrm{H}-20,2 \times \mathrm{OCH}_{3}\right), 3.91$ (3H, H-19, $\left.-\mathrm{OCH}_{3}\right), 5.16$ (1H, OH, BHP), 7.09 (2H, H-13, H-17), 7.10 (s, 2H, H-3, H-5), 10.15 (1H, C-11), $11.33(1 \mathrm{H}, \mathrm{NH}) .{ }^{13} \mathrm{C}-\mathrm{NMR} \delta$, ppm (Figure S11): $24.38(1 \mathrm{C}, \mathrm{C}-8), 30.35\left(6 \mathrm{C}, 2 \times-\mathrm{C}\left(\mathrm{CH}_{3}\right)_{3}\right), 34.41(2 \mathrm{C}$, 
$\left.2 \times-\mathrm{C}\left(\mathrm{CH}_{3}\right)_{3}\right), 36.54$ (1C, C-7), 56.35 (2C, C-18, C-20), 61.14 (1C, C-19), 106.00 (2C, C-13, C-17), 126.00 (2C, C-3, C-5), 127.33 (1C, C-4), 127.64 (1C, C-12), 136.13 (2C, C-2, C-6), 142.05 (1C, C-15), 150.11 (1C, C-9), 153.18 (1C, C-1), 153.65 (2C, C-14, C-16), 161.52 (1C, C-11), 162.60 (1C, C-10). HREIMS m/z $558.2335[\mathrm{M}]^{+}$(calcd for $\mathrm{C}_{28} \mathrm{H}_{38} \mathrm{O}_{4} \mathrm{~N}_{4} \mathrm{~S}_{2}$ 558.2334).

4-(3,5-Di-tert-butyl-4-hydroxybenzylideneamino)-3-((3,5-di-tert-butyl-4-hydroxybenzylthio)methyl)-1H-1,2, 4-triazole-5(4H)-thione (6). Prepared from 3,5-di-tert-butyl-4-hydroxybenzaldehyde $(0.63 \mathrm{mmol}$, $0.147 \mathrm{gm})$, recrystallized from 5:2 methanol-water to give $0.26 \mathrm{gm}$ of white solid $(69 \%)$. Mp $172-174{ }^{\circ} \mathrm{C}$. IR (KBr), $\mathrm{cm}^{-1}: v=3627-3605(2 \mathrm{OH}, 2 \mathrm{BHP}), 2872-2954(\mathrm{C}-\mathrm{H}$ of $t-\mathrm{Bu}), 1596-1581(\mathrm{C}=\mathrm{N}), 1233(\mathrm{C}=\mathrm{S})$. ${ }^{1} \mathrm{H}-\mathrm{NMR} \delta$, ppm (Figure S4): 1.41 (s, 18H, $2 \times t$-Bu, BHP-A), 1.45 (s, 18H, $2 \times t$-Bu, BHP-B), 3.70 (s, 2H, H-8), 3.72 (s, 2H, H-7), 5.15 (1H, OH, BHP-A), 5.70 (1H, OH, BHP-B), 7.09 (s, 2H, H-3, H-5), 7.69 (s, 2H, H-13, H-17), 9.87 (1H, C-11), 10.60-10.79 (1H, NH). ${ }^{13} \mathrm{C}-\mathrm{NMR} \delta \mathrm{ppm}$ (Figure S12): 24.39 (1C, C-8), $30.18\left(6 \mathrm{C}, 2 \times-\mathrm{C}\left(\mathrm{CH}_{3}\right)_{3}, \mathrm{BHP}-\mathrm{B}\right), 30.36\left(6 \mathrm{C}, 2 \times-\mathrm{C}\left(\mathrm{CH}_{3}\right)_{3}, \mathrm{BHP}-\mathrm{A}\right), 34.40\left(2 \mathrm{C}, 2 \times-\mathrm{C}\left(\mathrm{CH}_{3}\right)_{3}\right.$, BHP-A), 34.47 (2C, $\left.2 \times-\mathrm{C}\left(\mathrm{CH}_{3}\right)_{3}, \mathrm{BHP}-\mathrm{B}\right), 36.55$ (1C, C-7), 123.54 (1C, C-12), 126.00 (2C, C-3, C-5), 126.66 (2C, C-13, C-17), 127.43 (1C, C-4), 136.07 (2C, C-2, C-6), 136.65 (2C, C-14, C-16), 150.07 (1C, C-9), 153.14 (1C, C-1), 158.37 (1C, C-15), 162.65 (1C, C-10), 164.18 (1C, C-11). HREIMS m/z 596.3218 [M] $^{+}$ (calcd for $\mathrm{C}_{33} \mathrm{H}_{48} \mathrm{O}_{2} \mathrm{~N}_{4} \mathrm{~S}_{2}$ 596.3219).

4-(3,5-Di-tert-butyl-2-hydroxybenzylideneamino)-3-((3,5-di-tert-butyl-4-hydroxy benzylthio)methyl)-1H-1,2, 4-triazole-5(4H)-thione (7). Prepared from 3,5-di-tert-butyl-2-hydroxybenzaldehyde $(0.63 \mathrm{mmol}$, $0.147 \mathrm{gm})$, recrystallized from 5:2 methanol-water to give $0.25 \mathrm{gm}$ of white solid $(66 \%)$. Mp $126-128^{\circ} \mathrm{C}$. IR $(\mathrm{KBr}), \mathrm{cm}^{-1}: v=3609-3633(2 \mathrm{OH}, 2 \mathrm{BHP}), 2869-2954(\mathrm{C}-\mathrm{H}$ of $t-\mathrm{Bu}), 1610,1575(\mathrm{C}=\mathrm{N}), 1231(\mathrm{C}=\mathrm{S})$. ${ }^{1} \mathrm{H}-\mathrm{NMR} \delta$, ppm (Figure S5): $1.31(\mathrm{~s}, 9 \mathrm{H}, t$-Bu-C16, B) $1.42(\mathrm{~s}, 18 \mathrm{H}, 2 \times t$-Bu, BHP-A), $1.44(\mathrm{~s}, 9 \mathrm{H}$, t-Bu-C14, B), 3.65 (s, 2H, H-8), 3.70 (s, 2H, H-7), 5.17 (1H, OH, A), 7.12 (s, 2H, H-3, H-5), 7.19, 7.20 (d, 1H, H-15, $\left.{ }^{4} J=2 \mathrm{~Hz}\right), 7.52,7.53$ (d, 1H, H-17, $\left.{ }^{4} J=2 \mathrm{~Hz}\right), 9.96(1 \mathrm{H}, \mathrm{C}-11), 10.61(1 \mathrm{H}, \mathrm{OH}, \mathrm{B}), 11.24$ $(1 \mathrm{H}, \mathrm{NH}) .{ }^{13} \mathrm{C}-\mathrm{NMR} \delta$, ppm (Figure S13): $24.47(1 \mathrm{C}, \mathrm{C}-8), 29.50\left(3 \mathrm{C},-\mathrm{C}\left(\mathrm{CH}_{3}\right)_{3}, \mathrm{o}-\mathrm{OH}, \mathrm{B}\right), 30.37(6 \mathrm{C}, 2 \times$ $\left.-\mathrm{C}\left(\mathrm{CH}_{3}\right)_{3}, \mathrm{~A}\right), 31.46\left(3 \mathrm{C},-\mathrm{C}\left(\mathrm{CH}_{3}\right)_{3}, \mathrm{p}-\mathrm{OH}, \mathrm{B}\right), 34.33\left(1 \mathrm{C},-\mathrm{C}\left(\mathrm{CH}_{3}\right)_{3}, \mathrm{p}-\mathrm{OH}, \mathrm{B}\right), 34.43\left(2 \mathrm{C}, 2 \times-\mathrm{C}\left(\mathrm{CH}_{3}\right)_{3}\right.$, A), 35.30 (1C, $\left.-\mathrm{C}\left(\mathrm{CH}_{3}\right)_{3}, \mathrm{o}-\mathrm{OH}, \mathrm{B}\right), 36.35$ (1C, C-7), 115.35 (1C, C-12), 126.03 (2C, C-3, C-5), 127.11 (1C, C-4), 128.13 (1C, C-17), 130.20 (1C, C-15), 136.18 (2C, C-2, C-6), 137.56 (1C, C-14), 141.92 (1C, C-16), 148.58 (1C, C-9), 153.22 (1C, C-1), 157.35 (1C, C-13), 162.98 (1C, C-10), 168.69 (1C, C-11). HREIMS m/z $596.3228[\mathrm{M}]^{+}$(calcd for $\mathrm{C}_{33} \mathrm{H}_{48} \mathrm{O}_{2} \mathrm{~N}_{4} \mathrm{~S}_{2}$ 596.3219).

4-(4-(Benzyloxy)benzylideneamino)-3-((3,5-di-tert-butyl-4-hydroxybenzylthio)methyl)-1H-1,2,4-triazole-

5(4H)-thione (8). Prepared from 4-(benzyloxy)benzaldehyde ( $0.63 \mathrm{mmol}, 0.133 \mathrm{gm})$, and recrystallized from ethanol to give $0.30 \mathrm{gm}$ of white solid (83\%). Mp. 192-194 ${ }^{\circ} \mathrm{C}$. IR $(\mathrm{KBr}), \mathrm{cm}^{-1}: v=3635$ (free $\mathrm{OH}$, BHP), 2910-2948 (C-H of $\left.t-\mathrm{Bu},-\mathrm{CH}_{2}-\mathrm{O}\right), 1598,1577(\mathrm{C}=\mathrm{N}), 1236(\mathrm{C}=\mathrm{S}) .{ }^{1} \mathrm{H}-\mathrm{NMR} \delta, \mathrm{ppm}$ (Figure S6): $1.41(\mathrm{~s}, 18 \mathrm{H}, 2 \times t-\mathrm{Bu}, \mathrm{BHP}), 3.713(\mathrm{~s}, 2 \mathrm{H}, \mathrm{H}-7), 3.717(\mathrm{~s}, 2 \mathrm{H}, \mathrm{H}-8), 5.13(2 \mathrm{H}, \mathrm{H}-18) 5.16(1 \mathrm{H}, \mathrm{OH}), 7.02$, $7.04(\mathrm{~d}, 2 \mathrm{H}, \mathrm{H}-13, \mathrm{H}-17,3 \mathrm{~J}=8.6 \mathrm{~Hz}), 7.10(2 \mathrm{H}, \mathrm{H}-3, \mathrm{H}-5), 7.40(\mathrm{~m}, 1 \mathrm{H}, \mathrm{H}-22), 7.37-7.39(\mathrm{~m}, 2 \mathrm{H}, \mathrm{H}-21$, H-23), 7.42-7.44 (m, 2H, H-20, H-24), 7.78, 7.80 (d, 2H, H-14, H-16, $\left.{ }^{3} \mathrm{~J}=8.8 \mathrm{~Hz}\right), 10.13(1 \mathrm{H}, \mathrm{C}-11), 11.24$ $(1 \mathrm{H}, \mathrm{NH}) .{ }^{13} \mathrm{C}-\mathrm{NMR} \delta$, ppm (Figure S14): 24.30 (1C, C-8), 30.36 (6C, $\left.2 \times-\mathrm{C}\left(\mathrm{CH}_{3}\right)_{3}, \mathrm{BHP}\right), 34.42(2 \mathrm{C}, 2 \times$ $\left.-\mathrm{C}\left(\mathrm{CH}_{3}\right)_{3}\right), 36.53$ (1C, C-9), 70.26 (1C, C-18), 115.40 (2C, C-13, C-17), 125.28 (1C, C-12), 126.00 (2C, C-3, C-5), 127.40 (1C, C-19), 127.56 (2C, C-20, C-24), 128.34 (1C, C-22), 128.80 (2C, C-21, C-23), 130.85 (2C, C-14, C-16), 136.11 (2C, C-2, C-6), 136.26 (1C, C-4), 150.17 (1C, C-9), 153.15 (1C, C-1), 161.39 (1C, C-11), 162.43 (1C, C-15), 162.65 (1C, C-10). HREIMS $m / z$ $574.2408[\mathrm{M}]^{+}$(calcd for $\mathrm{C}_{32} \mathrm{H}_{38} \mathrm{O}_{2} \mathrm{~N}_{4} \mathrm{~S}_{2}$ 574.2436).

4-(Biphenyl-4-ylmethyleneamino)-3-((3,5-di-tert-butyl-4-hydroxybenzylthio)methyl)-1H-1,2,4-triazole-5(4H)-thione (9). Prepared from 4-phenylbenzaldehyde $(0.63 \mathrm{mmol}, 0.11 \mathrm{gm})$, and recrystallized from 5:2 ethanol-water to give $0.29 \mathrm{gm}$ of white solid (85\%). Mp. $185-187^{\circ} \mathrm{C}$. IR (KBr), $\mathrm{cm}^{-1}: v=3630$ (free OH, BHP), 3421 (NH), 2913-2951 (C-H of $t$-Bu), 1602 (C=N), 1237 (C=S). ${ }^{1} \mathrm{H}-\mathrm{NMR} \delta$, ppm (Figure S7): $1.41(\mathrm{~s}, 18 \mathrm{H}, 2 \times t-\mathrm{Bu}, \mathrm{BHP}), 3.72(\mathrm{~s}, 2 \mathrm{H}, \mathrm{H}-8), 3.75(\mathrm{~s}, 2 \mathrm{H}, \mathrm{H}-7), 5.16(1 \mathrm{H}, \mathrm{OH}), 7.11(2 \mathrm{H}, \mathrm{H}-3, \mathrm{H}-5)$, $7.39\left(\mathrm{t}, 1 \mathrm{H}, \mathrm{H}-21,{ }^{3} \mathrm{~J}=8 \mathrm{~Hz}\right), 7.47\left(\mathrm{t}, 2 \mathrm{H}, \mathrm{H}-20, \mathrm{H}-22,{ }^{3} \mathrm{~J}=7.6,{ }^{3} \mathrm{~J}=7.6 \mathrm{~Hz}\right), 7.62(\mathrm{~d}, 2 \mathrm{H}, \mathrm{H}-19, \mathrm{H}-23$, $\left.{ }^{3} J=8 \mathrm{~Hz}\right), 7.69(\mathrm{~d}, 2 \mathrm{H}, \mathrm{H}-14, \mathrm{H}-16,3 \mathrm{~J}=8 \mathrm{~Hz}), 7.91(\mathrm{~d}, 2 \mathrm{H}, \mathrm{H}-13, \mathrm{H}-17,3 \mathrm{~J}=8 \mathrm{~Hz}) .10 .43(1 \mathrm{H}, \mathrm{H}-11)$, 
10.89 (1H, NH). ${ }^{13} \mathrm{C}-\mathrm{NMR} \delta$, ppm (Figure S15): 24.31 (1C, C-8), $30.37\left(6 \mathrm{C}, 2 \times-\mathrm{C}\left(\mathrm{CH}_{3}\right)_{3}, \mathrm{BHP}\right), 34.42$ $\left(2 \mathrm{C}, 2 \times-\mathrm{C}\left(\mathrm{CH}_{3}\right)_{3}\right), 36.59$ (1C, C-7), 126.01 (2C, C-3, C-5), 127.28 (2C, C-13, C-17), 127.37 (1C, C-4), 127.71 (2C, C-14, C-16), 128.27 (1C, C-21), 129.06 (2C, C-20, C-22), 129.40 (2C, C-13, C-17), 131.44 (1C, C-12), 136.13 (2C, C-2, C-6), 140.04 (1C, C-18), 145.35 (1C, C-15), 150.34 (1C, C-9), 153.18 (1C, C-1), 160.57 (1C, C-11), 162.78 (1C, C-10). HREIMS $m / z$ 544.2324 [M] $]^{+}$(calcd for $\mathrm{C}_{31} \mathrm{H}_{36} \mathrm{~N}_{4} \mathrm{O}_{2} \mathrm{~S}_{2}$ 544.2331).

4-(4-Chlorobenzylideneamino)-3-((3,5-di-tert-butyl-4-hydroxybenzylthio)methyl)-1H-1,2,4-triazole-5(4H)-thione (10). Prepared from 4-chlorobenzaldehyde (0.63 mmol, $0.088 \mathrm{gm})$, and recrystallized from 5:1 methanol-water to give 0.24 gm of white solid, yield (76\%). Mp. 167-169 ${ }^{\circ} \mathrm{C}$. IR (KBr), $\mathrm{cm}^{-1}: v=3638$, $3616(\mathrm{OH}, \mathrm{BHP}), 29122950(\mathrm{C}-\mathrm{H}$ of $t-\mathrm{Bu}), 1593,1581(\mathrm{C}=\mathrm{N}), 1223(\mathrm{C}=\mathrm{S}), 1087(\mathrm{C}-\mathrm{Cl}$, stretching). ${ }^{1} \mathrm{H}-\mathrm{NMR} \delta$, ppm (Figure S8): 1.41 (s, 18H, $2 \times t$-Bu), 3.70 (s, 2H, H-7), 3.72 (s, 2H, H-8), $5.17(1 \mathrm{H}, \mathrm{OH})$, 7.10 (s, 2H, H-3, H-5), 7.22, 7.44 (d, 2H, H-13, H-17, $\left.{ }^{3} \mathrm{~J}=8 \mathrm{~Hz}\right), 7.76,7.78$ (d, 1H, H-14, H-16, ${ }^{3} \mathrm{~J}=8 \mathrm{~Hz}$ ), 10.47 (s, 1H, H-11), 11.07 (b, 1H, NH). ${ }^{13} \mathrm{C}-\mathrm{NMR} \delta$, ppm (Figure S16): 24.28 (1C, C-8), 30.36 (6C, $2 \times$ $-\mathrm{C}\left(\mathrm{CH}_{3}\right)_{3}, 34.42\left(2 \mathrm{C}, 2 \times-\mathrm{C}\left(\mathrm{CH}_{3}\right)_{3}\right), 36.53(1 \mathrm{C}, \mathrm{C}-7), 125.99$ (2C, C-3, C-5), $127.30(1 \mathrm{C}, \mathrm{C}-4), 129.44$ (2C, C-13, C-17), 130.00 (2C, C-14, C-16), 131.11 (1C, C-12), 136.15 (2C, C-2, C-6), 138.72 (1C, C-15), 150.26 (1C, C-9), 153.18 (1C, C-1), 159.09 (1C, C-11), 162.67 (1C, C-10). HREIMS m/z 502.1629 [M] ${ }^{+}$ (calcd for $\mathrm{C}_{25} \mathrm{H}_{31} \mathrm{ON}_{4} \mathrm{ClS}_{2}$ 502.1628).

\subsection{Antioxidant Assay}

In Vitro DPPH Free Radical Scavenging Assay

The DPPH radical scavenging assay was carried out according to the literature [69] with some modifications. Briefly, $1.0 \mathrm{~mL}$ of DPPH solution (200 $\mu \mathrm{M}$ in DMSO) was added to a range of various sample concentrations $(100,10,1,0.1$ and $0.01 \mu \mathrm{M})$. Then, 22.03-47.76 $\mathrm{mg}\left(1 \times 10^{-4} \mathrm{M}\right)$ of the test compound was dissolved in $1.0 \mathrm{~mL}$ DMSO (100\%) as a stock solution. This stock solution was then diluted to a range of final extraction concentrations of 100, 10, 1, 0.1 and $0.01 \mu \mathrm{M}$. As a negative control, the same DPPH concentration in DMSO without sample was used. Each assay was carried out in triplicate. The mixture was then incubated in the dark for $60 \mathrm{~min}$ at room temperature. Absorbance at $570 \mathrm{~nm}$ for each sample was then measured. BHT was used as a positive control. The free radical scavenging activity of the compounds was calculated as a percentage of radical inhibition using the following formula. Percentage of Inhibition $(\%)=((\mathrm{Ac}-\mathrm{As}) / \mathrm{Ac}) \times 100$, where As $=$ Absorbance of the compounds/positive control and $\mathrm{Ac}=$ Absorbance of control (DPPH solution and DMSO). To determine the concentration required to achieve $50 \%$ inhibition $\left(\mathrm{IC}_{50}\right)$ of the DPPH radical, the percentage of DPPH inhibition for each compound was plotted against the extract concentration.

\section{Conclusions}

SAR and rational design approaches involved integrating multiple radical-scavenging ability and manifold pharmacological activities in designing hybrid compounds with significantly enhanced radical-scavenging capacity and pharmacophores of the well-known antioxidant BHT. We have synthesized novel derivatives of the antioxidant BHT which are Schiff base-1,2,4-triazoles, as a new generation of MPAO. Experimental data of the present study revealed that the synthesized novel Schiff base-1,2,4-triazoles improved the antioxidant capacity of BHT (25.23\%) measured as the inhibition of DPPH to three-fold higher in compounds 6 (89.52\%) and 7 (79.61\%). The PASS and MPAO design approaches can be effectively used to determine lead compounds lacking undesirable side effects. PASS prediction of the Schiff base-1,2,4-triazoles were $\mathrm{Pa}<0.5$, which is confirmed experimentally, thus, there is a more than $50 \%$ chance that the Schiff base-1,2,4-triazole structures have not been reported with this activity, making them possible valuable lead compounds. These interesting results have stimulated us to consider BHT as a standard platform for new synthetic antioxidant projects. The products could play a vital role in repairing cellular damage, preventing various human diseases and in medical therapeutic application. 
Supplementary Materials: Supplementary materials can be accessed at: http://www.mdpi.com/ $1420-3049 / 21 / 7 / 874 /$ s1.

Acknowledgments: The authors would like to thank Grand Challenge (GC001C-14AET), Fundamental Research Grant Scheme (FP050-2014B) and (RP017C-13 AET) provided by the University of Malaya and Ministry of Higher Education, Malaysia (MOHE) for their cordial support in completing this work.

Author Contributions: Omar Saad, Abeer A. Alhadi, and Farkaad A. Kadir performed the experiments; Marzieh Yaeghoobi, Abdulsalam A. Matlob contributed reagents, materials and analysis tools; Sharifah Bee Abd Hamid, Azhar Ariffin, Noorsaadah Abdul Rahman and Wageeh A Yehye conceived and designed the experiments; Omar Saad, Abeer A. Alhadi, and Farkaad A. Kadir analyzed the data; Noorsaadah Abdul Rahman and Wageeh A. Yehye wrote the paper.

Conflicts of Interest: The authors declare no conflict of interest.

\section{References}

1. Birben, E.; Sahiner, U.M.; Sackesen, C.; Erzurum, S.; Kalayci, O. Oxidative stress and antioxidant defense. World Allergy Organ. J. 2012, 5, 9-19. [CrossRef] [PubMed]

2. Lee, J.; Koo, N.; Min, D. Reactive oxygen species, aging, and antioxidative nutraceuticals. Compr. Rev. Food Sci. Food Saf. 2004, 3, 21-33. [CrossRef]

3. Hsieh, C.; Ho, Y.; Lai, H.; Yen, G. Inhibitory effect of carnosine and anserine on DNA oxidative damage induced by $\mathrm{Fe}^{2+}, \mathrm{Cu}^{2+}$ and $\mathrm{H}_{2} \mathrm{O}_{2}$ in lymphocytes. J. Food Drug Anal. 2002, 10, 47-54.

4. Lazer, E.S.; Wong, H.C.; Possanza, G.J.; Graham, A.G.; Farina, P.R. Antiinflammatory 2,6-di-tert-butyl-4-(2-arylethenyl)phenols. J. Med. Chem. 1989, 32, 100-104. [CrossRef] [PubMed]

5. Moore, G.; Swingle, K. 2,6-Di-tert-butyl-4-(2-thenoyl) phenol (r-830): A novel nonsteroidal anti-inflammatory agent with antioxidant properties. Agents Actions 1982, 12, 674-683. [CrossRef] [PubMed]

6. Grosso, P.; Vogl, O. Functional polymers. Polym. Bull. 1985, 14, 245-250.

7. Dacre, J. The metabolism of 3,5-di-tert-butyl-4-hydroxytoluene and 3,5-di-tert-butyl-4-hydroxybenzoic acid in the rabbit. Biochem. J. 1961, 78, 758-766. [CrossRef] [PubMed]

8. Dröge, W. Free radicals in the physiological control of cell function. Physiol. Rev. 2002, 82, 47-95. [CrossRef] [PubMed]

9. Schöneich, C. Reactive oxygen species and biological aging: A mechanistic approach. Exp. Gerontol. 1999, 34, 19-34. [CrossRef]

10. Sahinoglu, T.; Stevens, C.R.; Bhatt, B.; Blake, D.R. The role of reactive oxygen species in inflammatory disease: Evaluation of methodology. Methods 1996, 9, 628-634. [CrossRef] [PubMed]

11. Petrone, W.; English, D.; Wong, K.; McCord, J. Free radicals and inflammation: Superoxide-dependent activation of a neutrophil chemotactic factor in plasma. Proc. Natl. Acad. Sci. USA 1980, 77, 1159-1163. [CrossRef] [PubMed]

12. Schöneich, C. Methionine oxidation by reactive oxygen species: Reaction mechanisms and relevance to alzheimer's disease. Biochim. Biophys. Acta Proteins Proteom. 2005, 1703, 111-119. [CrossRef] [PubMed]

13. Oka, M.; Tachibana, M.; Noda, K.; Inoue, N.; Tanaka, M.; Kuwabara, K. Relevance of anti-reactive oxygen species activity to anti-inflammatory activity of components of eviprostat, a phytotherapeutic agent for benign prostatic hyperplasia. Phytomedicine 2007, 14, 465-472. [CrossRef] [PubMed]

14. Kirkinezos, I.G.; Moraes, C.T. Reactive oxygen species and mitochondrial diseases. Semin. Cell Dev. Biol. 2001, 12, 449-457. [CrossRef] [PubMed]

15. De Maria, N.; Colantonl, A.; Fagiuoli, S.; Liu, G.-J.; Rogers, B.K.; Farinati, F.; van Thiel, D.H.; Floyd, R.A. Association between reactive oxygen species and disease activity in chronic hepatitis c. Free Radic. Biol. Med. 1996, 21, 291-295. [CrossRef]

16. Smith, C.; Zhang, Y.; Koboldt, C.; Muhammad, J.; Zweifel, B.; Shaffer, A.; Talley, J.; Masferrer, J.; Seibert, K.; Isakson, P. Pharmacological analysis of cyclooxygenase-1 in inflammation. Proc. Natl. Acad. Sci. USA 1998, 95, 13313-13318. [CrossRef] [PubMed]

17. Victor, V.; McCreath, K.; Rocha, M. Recent progress in pharmacological research of antioxidants in pathological conditions: Cardiovascular health. Recent Pat. Anti-Infect. Drug Discov. 2006, 1, 17-31. [CrossRef]

18. Hertog, M.G.L.; Feskens, E.J.M.; Kromhout, D.; Hollman, P.C.H.; Katan, M.B. Dietary antioxidant flavonoids and risk of coronary heart disease: The zutphen elderly study. Lancet 1993, 342, 1007-1011. [CrossRef] 
19. Braid, M. Antioxidant Lubricant Compositions. United States Patent 4198303, 4 April 1980.

20. Lyons, B.J. Antioxidants of Bisphenolic Polymers. Patent US3986981A, 19 October 1976.

21. Chang, D. Clear Coat/Color Coat Finish Containing an Antioxidant and an Ultraviolet Light Stabilizer. Patent US4208465A, 17 June 1980.

22. Yamada, K.; Hung, P.; Yoshimura, K.; Taniguchi, S.; Ou Lim, B.; Sugano, M. Effect of unsaturated fatty acids and antioxidants on immunoglobulin production by mesenteric lymph node lymphocytes of sprague-dawley rats. J. Biochem. 1996, 120, 138-143. [CrossRef] [PubMed]

23. Hilton, J. Antioxidants: Function, types and necessity of inclusion in pet foods. Can. Vet. J. 1989, 30, 682-684. [PubMed]

24. Stecher, P. Butylated hydroxytoluene. In The Merck Index, 8th ed.; O'Neil, M.J., Ed.; Merck Research Laboratories: Rahway, NJ, USA, 1968; p. 179.

25. Stuckey, B. Antioxidants as food stabilizers. Handb. Food Addit. 1972, 185, 204.

26. Ariffin, A.; Rahman, N.A.; Yehye, W.A.; Alhadi, A.A.; Kadir, F.A. Pass-assisted design, synthesis and antioxidant evaluation of new butylated hydroxytoluene derivatives. Eur. J. Med. Chem. 2014, 87, 564-577. [CrossRef] [PubMed]

27. Yehye, W.A.; Abdul Rahman, N.; Alhadi, A.A.; Khaledi, H.; Weng, N.S.; Ariffin, A. Butylated hydroxytoluene analogs: Synthesis and evaluation of their multipotent antioxidant activities. Molecules 2012, 17, 7645-7665. [CrossRef] [PubMed]

28. Shakir, R.; Ariffin, A.; Abdulla, M. Synthesis of new 2,5-di-substituted 1,3,4-oxadiazoles bearing 2,6-di-tert-butylphenol moieties and evaluation of their antioxidant activity. Molecules 2014, 19, 3436-3449. [CrossRef] [PubMed]

29. Ueda, S.; Nagasawa, H. Facile synthesis of 1,2,4-triazoles via a copper-catalyzed tandem addition-oxidative cyclization. J. Am. Chem. Soc. 2009, 131, 15080-15081. [CrossRef] [PubMed]

30. Rani, S.; Agaiah, B.; Sarangapani, M. Antioxidant and DNA binding study 3,3'-(5,5'-methylene bis(3-mercapto-4H-1,2,4-triazole-5,4-diyl) bis (azan-1-yl-1-ylidene) diindolin-2-ones. Int. J. Pharm. Technol. 2010, 2, 366-374.

31. Palaska, E.; Sahin, G.; Kelicen, P.; Durlu, N.T.; Altinok, G. Synthesis and anti-inflammatory activity of 1-acylthiosemicarbazides, 1,3,4-oxadiazoles, 1,3,4-thiadiazoles and 1,2,4-triazole-3-thiones. Farmaco 2002, 57, 101-107. [CrossRef]

32. Navidpour, L.; Shafaroodi, H.; Abdi, K.; Amini, M.; Ghahremani, M.H.; Dehpour, A.R.; Shafiee, A. Design, synthesis, and biological evaluation of substituted 3-alkylthio-4,5-diaryl-4H-1,2,4-triazoles as selective cox-2 inhibitors. Bioorg. Med. Chem. 2006, 14, 2507-2517. [CrossRef] [PubMed]

33. Wujec, M.; Pitucha, M.; Dobosz, M.; Kosikowska, U.; Malm, A. Synthesis and potential antimycotic activity of 4-substituted-3-(thiophene-2-yl-methyl)- $\delta 2-1,2,4$-triazoline-5-thiones. Acta Pharm. Short Commun. 2004, 54, 251-260.

34. Valentina, P.; Ilango, K.; Deepthi, M.; Harusha, P.; Pavani, G.; Sindhura, K.; Keerthanan, C. Antioxidant activity of some substituted 1,2,4-triazo-5-thione schiff base. J. Pharm. Sci. 2009, 1, 74-77.

35. Poroikov, V.; Filimonov, D.; Lagunin, A.; Gloriozova, T.; Zakharov, A. Pass: Identification of probable targets and mechanisms of toxicity. SAR QSAR Environ. Res. 2007, 18, 101-110. [CrossRef] [PubMed]

36. Kadir, F.A.; Kassim, N.M.; Abdulla, M.A.; Yehye, W.A. Pass-predicted vitex negundo activity: Antioxidant and antiproliferative properties on human hepatoma cells-an in vitro study. BMC Complement. Altern. Med. 2013, 13, 343. [CrossRef] [PubMed]

37. Stepanchikova, A.V.; Lagunin, A.A.; Filimonov, D.A.; Poroikov, V.V. Prediction of biological activity spectra for substances: Evaluation on the diverse sets of drug-like structures. Curr. Med. Chem. 2003, 10, 225-233. [CrossRef] [PubMed]

38. Anzali, S.; Barnickel, G.; Cezanne, B.; Krug, M.; Filimonov, D.; Poroikov, V. Discriminating between drugs and nondrugs by prediction of activity spectra for substances (pass). J. Med. Chem. 2001, 44, 2432-2437. [CrossRef] [PubMed]

39. Kadir, F.; Kassim, N.B.M.; Abdulla, M.A.; Kamalidehghan, B.; Ahmadipour, F.; Yehye, W. Pass-predicted hepatoprotective activity of caesalpinia sappan in thioacetamide-induced liver fibrosis in rats. Sci. World J. 2014. in press. [CrossRef] [PubMed] 
40. Delmas, F.; di Giorgio, C.; Robin, M.; Azas, N.; Gasquet, M.; Detang, C.; Costa, M.; Timon-David, P.; Galy, J.-P. In vitro activities of position 2 substitution-bearing 6-nitro-and 6-amino-benzothiazoles and their corresponding anthranilic acid derivatives against leishmania infantum and trichomonas vaginalis. Antimicrob. Agents Chemother. 2002, 46, 2588-2594. [CrossRef] [PubMed]

41. Di Giorgio, C.; Delmas, F.; Filloux, N.; Robin, M.; Seferian, L.; Azas, N.; Gasquet, M.; Costa, M.; Timon-David, P.; Galy, J.-P. In vitro activities of 7-substituted 9-chloro and 9-amino-2-methoxyacridines and their bis-and tetra-acridine complexes against leishmania infantum. Antimicrob. Agents Chemother. 2003, 47, 174-180. [CrossRef] [PubMed]

42. Di Giorgio, C.; Delmas, F.; Ollivier, E.; Elias, R.; Balansard, G.; Timon-David, P. In vitro activity of the $\beta$-carboline alkaloids harmane, harmine, and harmaline toward parasites of the species leishmania infantum. Exp. Parasitol. 2004, 106, 67-74. [CrossRef] [PubMed]

43. Mathew, V.; Keshavayya, J.; Vaidya, V.P. Heterocyclic system containing bridgehead nitrogen atom: Synthesis and pharmacological activities of some substituted 1,2,4-triazolo[3,4-b]-1,3,4-thiadiazoles. Eur. J. Med. Chem. 2006, 41, 1048-1058. [CrossRef] [PubMed]

44. Zamani, K.; Faghiiii, K.; Sangi, M.R.; Zolgharnein, J. Synthesis of some new substituted 1,2,4-triazole and 1,3,4-thiadiazole and their derivatives. Turk. J. Chem. 2003, 27, 119-126.

45. Shakir, R.M.; Ariffin, A.; Ng, S.W. Ethyl 4-[(3,5-di-tert-butyl-2-hydroxybenzylidene)amino]benzoate. Acta Crystallogr. Sect. E 2010, 66, o2915. [CrossRef] [PubMed]

46. Eklund, P.C.; Langvik, O.K.; Warna, J.P.; Salmi, T.O.; Willfor, S.M.; Sjoholm, R.E. Chemical studies on antioxidant mechanisms and free radical scavenging properties of lignans. Org. Biomol. Chem. 2005, 3, 3336-3347. [CrossRef] [PubMed]

47. Sharma, O.P.; Bhat, T.K. DPPH antioxidant assay revisited. Food Chem. 2009, 113, 1202-1205. [CrossRef]

48. Ionita, P. Is DPPH stable free radical a good scavenger for oxygen active species. Chem. Papers 2005, 59, $11-16$.

49. Bondet, V.; Brand-Williams, W.; Berset, C. Kinetics and mechanisms of antioxidant activity using the DPPH. Free radical method. Lebensm. Wiss. Technol. 1997, 30, 609-615. [CrossRef]

50. Dayan, N. Skin Aging Handbook-An Integrated Approach to Biochemistry and Product Development; William Andrew Publishing: Norwich, NY, USA, 2008; p. 352.

51. Huang, D.; Ou, B.; Prior, R.L. The chemistry behind antioxidant capacity assays. J. Agric. Food Chem. 2005, 53, 1841-1856. [CrossRef] [PubMed]

52. Cano, A.; Acosta, M.; Arnao, M. A method to measure antioxidant activity in organic media: Application to lipophilic vitamins. Redox Rep. 2000, 5, 365-370. [CrossRef] [PubMed]

53. Brand-Williams, W.; Cuvelier, M.; Berset, C. Use of a free radical method to evaluate antioxidant activity. LWT Food Sci. Technol. 1995, 28, 25-30. [CrossRef]

54. Kajiyama, T.; Ohkatsu, Y. Effect of para-substituents of phenolic antioxidants. Polym. Degrad. Stab. 2001, 71, 445-452. [CrossRef]

55. Lucarini, M.; Pedulli, G.F.; Cipollone, M. Bond dissociation enthalpy of $\alpha$-tocopherol and other phenolic antioxidants. J. Org. Chem. 1994, 59, 5063-5070. [CrossRef]

56. Scott, G. Antioxidants. Bull. Chem. Soc. Jpn. 1988, 61, 165-170. [CrossRef]

57. Yehye, W.A.; Rahman, N.A.; Ariffin, A.; Abd Hamid, S.B.; Alhadi, A.A.; Kadir, F.A.; Yaeghoobi, M. Understanding the chemistry behind the antioxidant activities of butylated hydroxytoluene (bht): A review. Eur. J. Med. Chem. 2015, 101, 295-312. [CrossRef] [PubMed]

58. Barclay, L.R.C.; Vinqvist, M.R. Phenols as Antioxidants; John Wiley and Sons, Ltd.: Chichester, UK, 2003; pp. 839-908.

59. Klein, E.; Lukeš, V.; Cibulková, Z. On the energetics of phenol antioxidants activity. Pet. Coal 2005, 47, 33-39.

60. Pizzi, A.; Mittal, K.L. Handbook of Adhesive Technology, 2nd ed.; Pizz, A., Mittal, K.L., Eds.; Marcel Dekker: New York, NY, USA, 2003.

61. Denisov, E.T.; Afanas'ev, I.B. Oxidation and Antioxidants in Organic Chemistry and Biology; CRC Press: Boca Raton, FL, USA, 2005; p. 1024.

62. Luedtke, A.E.; Timberlake, J.W. Effect of oxidized states of heteroatoms and of orthogonal Pi. Systems on radical stabilities. J. Org. Chem. 1985, 50, 268-270. [CrossRef] 
63. Escobar-Valderrama, J.; Garcia-Tapia, J.; Ramirez-Ortiz, J.; Rosales, M.; Toscano, R.; Valdes-Martinez, J. Crystal, molecular and electronic structure of 1-H-3-methyl-4-amine-5-thione-1,2,4-triazol. Can. J. Chem. 1989, 67, 198-201. [CrossRef]

64. Khan, I.; Ali, S.; Hameed, S.; Rama, N.; Hussain, M.; Wadood, A.; Uddin, R.; Ul-Haq, Z.; Khan, A. Synthesis, antioxidant activities and urease inhibition of some new 1,2,4-triazole and 1,3,4-thiadiazole derivatives. Eur. J. Med. Chem. 2010, 45, 5200-5207. [CrossRef] [PubMed]

65. Zhang, H. Structure-activity relationships and rational design strategies for radical-scavenging antioxidants. Curr. Comput. Aided Drug Des. 2005, 1, 257-273. [CrossRef]

66. Nazarbahjat, N.; Nordin, N.; Abdullah, Z.; Abdulla, M.; Yehye, W.; Halim, S.; Kee, C.; Ariffin, A. New thiosemicarbazides and 1,2,4-triazolethiones derived from 2-(ethylsulfanyl) benzohydrazide as potent antioxidants. Molecules 2014, 19, 11520-11537. [CrossRef] [PubMed]

67. Amorati, R.; Lucarini, M.; Mugnaini, V.; Pedulli, G. Antioxidant activity of o-bisphenols: The role of intramolecular hydrogen bonding. J. Org. Chem. 2003, 68, 5198-5204. [CrossRef] [PubMed]

68. Liu, Z.Q.; Wu, D. How many peroxyl radicals can be scavenged by hydroxyl-substituted schiff bases in the oxidation of linoleic acid? J. Phys. Org. Chem. 2009, 22, 308-312. [CrossRef]

69. Blois, M.S. Antioxidant determination by the use of a stable free radical. Nature 1958, 181, 1199-1200. [CrossRef]

Sample Availability: Samples of the compounds are not available.

(C) 2016 by the authors; licensee MDPI, Basel, Switzerland. This article is an open access article distributed under the terms and conditions of the Creative Commons Attribution (CC-BY) license (http://creativecommons.org/licenses/by/4.0/). 